\title{
Comment
}

\section{The Descendibility of the Right of Publicity: Is There Commercial Life After Death?}

\author{
Peter L. Felcher $\dagger^{\text {and Edward L. Rubin }}{ }^{\ddagger}$
}

I

When the right of publicity was first articulated to protect the ability of baseball players to profit from the use of their photographs on bubble gum cards, ${ }^{1}$ there was little indication that its descendibility would become a major issue. In recent years, however, courts have been besieged by litigants who claim that they should exercise control over the publicity rights of their famous and departed forebears. ${ }^{2}$ The descendibility of publicity rights has proved to be a troublesome issue, because of both the nature of the claims presented and the distinctions to be made in separating the private and the public domains.

Two of the most recent and significant cases involve Elvis Presley, whose ability to create controversy apparently has been unimpaired by death. During his lifetime, Presley entered into a contract with Boxcar Enterprises in which he conveyed the exclusive right to use his name and likeness for commercial purposes. Since Presley's death, Boxcar's licensee, Factors Etc., Inc., has been involved in several suits relating to the exploitation of Presley's attributes by others. In Factors Etc., Inc. v. Pro Arts, Inc., ${ }^{3}$ the Second Circuit enforced the Presley-Boxcar contract, enjoining the unauthorized sale by Pro Arts of a poster bearing Presley's photograph. Although the court declined to rule that the

$\dagger$ Partner, Paul, Weiss, Rifkind, Wharton \& Garrison, New York, New York.

$\ddagger$ Law Clerk to the Honorable Jon O. Newman, Court of Appeals for the Second Circuit.

1. See Haelan Laboratories, Inc. v. Topps Chewing Gum, Inc., 202 F.2d 866 (2d Cir.), cert. denied, 346 U.S. 816 (1953).

2. See, e.g., Memphis Dev. Foundation v. Factors Etc., Inc., No. 79-1270 (6th Cir. March 6, 1980); Factors Etc., Inc. v. Pro Arts, Inc., 579 F.2d 215 (2d Cir. 1978), cert. denied, 440 U.S. 908 (1979); Hicks v. Casablanca Records \& Filmworks, 464 F. Supp. 426 (S.D.N.Y. 1978); Price v. Hal Roach Studios, Inc., 400 F. Supp. 836 (S.D.N.Y. 1975); Lugosi v. Universal Pictures, 25 Cal. 3d 8I3, 603 P.2d 425, 160 Cal. Rptr. 323 (1979); Guglielmi v. Spelling-Goldberg Prods., 25 Cal. 3d 860, 603 P.2d 454, 160 Cal. Rptr. 352 (1979).

3. 579 F.2d 215 (2d Cir. 1978), cert. denied, 440 U.S. 908 (1979). 
right of publicity in general can be inherited, ${ }^{4}$ it held that the "exclusive right to exploit the Presley name and likeness, because exercised during Presley's life, survived his death."J

A few months ago, in Memphis Development Foundation v. Factors Etc., Inc., ${ }^{6}$ the Sixth Circuit reached a different conclusion. ${ }^{7}$ The case arose when the Foundation solicited public contributions for a large bronze statue to commemorate Presley and distributed eight-inch pewter replicas of the design to anyone who donated twenty-five dollars or more. The Foundation brought a declaratory judgment action seeking a ruling that the Factors license would not prevent the erection of the statue or the distribution of the pewter replicas. The district court permitted the building of the statue but not the distribution of the replicas. ${ }^{8}$ The Sixth Circuit found no bar to any use of the name or likeness of Presley, and through Judge Merritt reversed.

In a carefully reasoned opinion, the court took issue with an article by the present authors that recently had appeared in these pages, ${ }^{0}$ which argued that a person's right of publicity should be inheritable if it has been translated into a contractual right during his lifetime. Such a rule, according to the Sixth Circuit, would create a variety of difficulties, given the personal nature of the right, its possible conflict with the First Amendment, and the problems in limiting both the scope of the right and its temporal extent. In addition, the court found that the rule would not sufficiently fulfill the social policy underlying recognition of the right. Consequently, the court concluded that the right of publicity, while properly recognized during a person's lifetime, should terminate at his death under all circumstances.

4. Id. at 222 n.11.

5. Id. at 222. The California Supreme Court implied a similar view in Lugosi v. Universal Pictures, 25 Cal. 3d 813, 603 P.2d 425, 160 Cal. Rptr. 323 (1979), by denying the heirs of Bela Lugosi exclusive publicity rights in his attributes upon finding that such rights were not exploited by Lugosi during his lifetime.

6. No. 79-1270 (6th Cir. March 6, 1980).

7. Technically, the two decisions are not in direct conflict, because Pro Arts was a diversity case governed by New York law, and Memphis Development Foundation, also a diversity case, was governed by Tennessee law. However, both courts noted that there were few applicable state cases, see 579 F.2d at 221; No. 79-1270, slip op. at 4, and proceeded to apply general law. In fact, the right of publicity, and related doctrines of misappropriation and unfair competition, have been regarded as an area in which general law prevails. See, e.g., Kellogg Co. v. National Biscuic Co., 305 U.S. 111 (1938) (Brandeis, J.) (applying general law to unfair competition claim despite recent rejection of general law in Erie R.R. Co. v. Tompkins, 304 U.S. 64 (1938)). Thus the disagreement between the two courts, even though originating in diversity cases, is tantamount to a conflict between the circuits.

8. Memphis Dev. Foundation v. Factors Etc., Inc., 441 F. Supp. 1323 (W.D. Tenn. 1977).

9. Felcher \& Rubin, Privacy, Publicity, and the Portrayal of Real People by the Media, 88 YALE L.J. 1577, 1618-20 (1979). 
Most courts and commentators have approached the problem of determining whether the right of publicity should be inheritable by using analogies. The first analogy that seemed to suggest itself was to the right of privacy, from which the right of publicity had evolved.10 Because privacy had long been held to be a personal right, terminating with the death of the individual, ${ }^{11}$ this analogy led to the conclusion that publicity rights were similarly uninheritable. ${ }^{12}$ The Sixth Circuit came to the same conclusion by analogizing publicity rights to defamation, an area of the law concerned with personal reputation and closely related to publicity rights. ${ }^{13}$

In recent years, an analogy to property rights also has been suggested. Because the right of publicity protects the individual against portrayals that expropriate the commercial value of his name or likeness, and because the individual generally makes use of the exclusive control secured by this protection to sell the right to use his name or likeness, publicity rights came to be regarded as a form of property. ${ }^{14}$ This type of analogy leads to an opposite conclusion about descendibility; most forms of property are devisable, and it seems reasonable to regard a person's property right in his name or likeness to be devisable as well. ${ }^{15}$

The strength of an analogical approach is that once the equivalence is established, previously developed rationales and conclusions can be brought to bear on the new situation; application of privacy, defamation, or property analogies to the area of publicity brings previously developed rationales and conclusions for deciding issues like descendibility. But a major difficulty with analogies, derived from precisely the same source as their strength, is that they tend to impose a mature, elaborated system on what may well be an unformulated situation.

10. Id. at 1588-89; Nimmer, The Right of Publicity, 19 LAw \& Contemp. Prob. 203 (1954).

11. See, e.g., Maritote v. Desilu Prods., Inc., 345 F.2d 418, 420 (7th Cir.), cert. denied, 382 U.S. 883 (1965); Gruschus v. Curtis Publishing Co., 342 F.2d 775, 776 (10th Cir. 1965); W. Prosser, HandBook of the LAW of TorTs $\S 117$, at 814-15 (4th ed. 1971).

12. See, e.g., James v. Screen Gems, Inc., 174 Cal. App. 2d 650, 653-54, 344 P.2d 799, 801 (1959); Schumann v. Loew's, Inc., 144 N.Y.S.2d 27, 30-31 (Sup. Ct. 1955).

13. No. 79.1270, slip op. at 6. It is well established that the right to recover for defamation vanishes at death. See, e.g., Wender v. Hamburger, 393 F.2d 365 (D.C. Cir. 1968); Thompson v. Curtis Publishing Co., 193 F.2d 953 (3d Cir. 1952).

14. See, e.g., Cepeda v. Swift \&. Co., 415 F.2d 1205, 1206 (8th Cir. 1969); Uhlaender v. Henricksen, 316 F. Supp. 1277, 1282 (D. Minn. 1970).

15. See, e.g., Price v. Hal Roach Studios, Inc., 400 F. Supp. 836, 844 (S.D.N.Y. 1975); Lugosi v. Universal Pictures, 172 U.S.P.Q. (BNA) 541, 551 (Super. Ct. L.A. County 1972), rev'd, 25 Cal. 3d 813, 603 P.2d 425, 160 Cal. Rptr. 323 (1979). 
The choice of the analogy may not be fully justifiable, and the analogy's application to the situation may carry with it a misleading certainty. In the present case, none of the analogies of privacy, defamation, or property law seems correct to apply to the publicity issue; once one is chosen, however, it resolves the descendibility issue with a force much too decisive for the complex and subtle nature of the problem.

An alternative to analogy is what might be termed a policy analysis. This involves examination, or reexamination, of the underlying social policies on which the right is based. This type of approach avoids the deceptive certainty and overly conclusive nature of analogy; however, the result is often unspecific generality. Nonetheless, identification and analysis of the applicable social policy can assist in the selection of the appropriate analogy to apply, and the interaction of both can achieve the proper result.

The social policy underlying the right of publicity is encouragement of individual enterprise and creativity by allowing people to profit from their own efforts. ${ }^{16}$ When publicity rights are involved, recognition must be given, however, to the countervailing policy of the First Amendment interest in the free use of information. Consequently, publicity rights must be limited to those areas outside the scope of First Amendment interest where other social policies prevail.

Ultimately, each of the three analogies suggested-privacy, defamation, and property-fails to provide a satisfactory solution to the issue of the descendibility of publicity rights. The type of interest protected in a privacy action is an individual's desire to avoid unwanted public exposure. It is understandable that such a right should vanish at death, because it is primarily concerned with the personal sensibilities of an individual. The same may be said about defamation, for here the sanction is against unwanted public statements harmful to an individual's reputation. But publicity rights protect the individual's ability to profit from public exposure, not to avoid it. Because this right is more commercial in its nature, and generally is useful only when it is transferred, there is no reason to assume that it cannot be devisable as well.

On the other hand, property rights are designed to grant individuals the power to exercise control over some entity, and to exclude others from exercising such control, largely for the purpose of creating economic incentives. Because passing on the property to others may have as great a motivational effect as acquiring that property for oneself, it

16. Zacchini v. Scripps-Howard Broadcasting Co., 433 U.S. 562, 573, 576 (1977). 
makes sense that property is deemed to be devisable. The exclusive control involved in most property rights, however, does not intrude upon any constitutional principle. Yet when an individual exercises control through a right of publicity, there often is a significant conflict between that action and the First Amendment interest in the general use of information. It would be inappropriate to permit this right to be controlled by a person or his heirs in the more unrestricted manner that applies to property in general.

\section{III}

This analysis of publicity rights calls into question the use of privacy, defamation, and property as analogies. It also suggests, however, a more appropriate analogy in their place. This analogy is to the copyright law. ${ }^{17}$ Like the right of publicity, the underlying policy of copyright is to provide an incentive for enterprise and creativity by allowing individuals to benefit from their personal efforts. ${ }^{18}$ Copyright is also similar to the right of publicity in that the control it grants involves a substantial possibility of conflict with the First Amendment. ${ }^{19}$ These similarities suggest that copyright, not privacy, defamation, or property, is the proper analogy for defining the operation of the right of publicity. 20

The copyright analogy provides an answer to the question of de-

17. See 17 U.S.C. $\$ \S 101-810$ (Supp. 1978).

18. U.S. CoNST. art. I, $\$ 8, \mathrm{cl} .8$ (copyright and patent power provided "[t]o promote the Progress of Science and useful Arts"); see Mazer v. Stein, 347 U.S. 201, 219 (1954).

In Memphis Development Foundation, the court took issue with the view that the descendibility of publicity rights could serve as motivation for enterprise. In its view, "[t]he desire to exploit fame for the commercial advantage of one's heirs is . . a weak principle of motivation" in contrast to "the desire to achieve success or excellence in a chosen field." No. 79-1270, slip op. at 4-5. The court suggested that even the desire for financial gain during one's life is secondary to the psychic rewards of excellence. Although the power of psychic reward may be conceded, this is generally beyond the reach of conscious social policy. And any exposure to the modern-day entertainment industry will provide ample evidence that the force of tangible incentives is far from negligible. The fact that people enjoy a particular pursuit does not mean that they will continue to devote their lives to it if no economic advantages are forthcoming. Even the eighteenthcentury framers of our Constitution saw fit, in the copyright clause, to reinforce the pleasures of excellence with the rewards of economic gain.

19. See, e.g., Nimmer, Does Copyright Abridge the First Amendment Guarantees of Free Speech and Press? 17 U.C.L.A. L. Rev. 1180 (1970); Sobel, Copyright and the First Amendment: A Gathering Storm? 19 CopYright L. SyMp. 43 (1971).

20. This view has been adopted by the Supreme Court in Zacchini v. Scripps-Howard Broadcasting Co., 433 U.S. 562, 573 (1977) (interest protected under the right of publicity "is closely analogous to the goals of patent and copyright law, focusing on the right of the individual to reap the reward of his endeavors and having little to do with protecting feelings or reputation"); see Factors Etc., Inc. v. Pro Arts, Inc., 579 F.2d 215, 220 (2d Cir. 1978), cert. denied, 440 U.S. 908 (1979) (quoting Zacchini). 
scendibility of publicity rights, both with respect to the scope of the protection that should be allowed and to the temporal extent of that protection. Copyrights are intended to be inherited and the interests of heirs are recognized under the copyright laws. ${ }^{21}$ The rationale is that the ability to leave the copyright to one's heirs, like the ability to profit from one's creative efforts in the first place, will have a significant motivational effect. Because of the possible conflict with free speech, however, limits have been placed on the scope of copyright protection..$^{22}$ A copyright extends only to the author's particular and individual expression; material previously in the public domain incorporated in a copyrighted work will not be protected. The author may not protect the ideas and general themes that form the basis of his work. Portions of a copyrighted work may be used by others under fair use concepts. In addition, there are certain notice and registration requirements; if the author is not sufficiently motivated to comply, under certain circumstances the work will not be protected, or full remedies will not be available.

These same concepts can appropriately be applied to publicity rights in general, and to the descendibility question in particular. To avoid conflicts with the First Amendment, the right of publicity should be, and for the most part has been, limited to essentially commercial products, where the First Amendment interest is relatively low. ${ }^{23}$ To minimize any remaining conflicts with free speech, publicity rights should be further limited to situations in which there is evidence that they will fulfill the social policy of motivating enterprise and creative effort. In general this means that these rights should be limited-as in fact they are-to situations in which the individual earns at least part of his livelihood from the publicity that is to be protected. ${ }^{24}$ As far as the

21. 17 U.S.C. $\$ 201$ (d)(1) (Supp. 1978). The period of copyright protection provided in the Copyright Act is the life of the author plus fifty years, a clear indication that copyrights are to be inherited. Id. $\$ 302(a)$. Also, certain statutory beneficiaries are given specific rights under certain circumstances to terminate grants of rights under copyrights and to control the making of new grants, a clear recognition of the interests of heirs in copyrights. $I d$. $\$ \S 203,304$ (c).

22. The Sixth Circuit, in analyzing the social policy underlying the right of publicity, concluded "that making the right of publicity inheritable would not significantly inspire the creative endeavors of individuals in our society." It found "that whatever minimal benefit to society may result from the added motivation and extra creativity supposedly encouraged by allowing a person to pass on his fame for the commercial use of his heirs," it would not outweigh the value of free access to a person's name and likeness for commercial purposes after death regardless of the extent to which those attributes were exploited by the person during his lifetime. Memphis Dev. Foundation v. Factors Etc., Inc., No. 79-1270, slip op. at 5, 7 (6th Cir. March 6, 1980).

23. See Felcher \& Rubin, supra note 9 , at $1597-99,1606$.

24. This is to satisfy the requirement of identifiable harm to a demonstrated ability to profit from one's own attributes, which is protected to encourage individuals to pursue socially desirable activities. See Felcher \& Rubin, sufra note 9, at 1613-15. 
specific issue of descendibility is concerned, these rights should be protected only when they have been translated into concrete form through the medium of a contract. Barring such action, there is no specific indication that the individual was motivated by any desire to transfer the benefit of his publicity rights to others; to permit descendibility under these circumstances would not fulfill the social policy of encouraging enterprise and creativity. ${ }^{25}$

If a person is permitted to devise his right of publicity by means of a contract, the further question arises of whether any time limit will be placed upon the inherited right. As a practical matter, this is probably not a source of major concern, because publicity rights generally tend to lose their useful commercial value after a reasonable period of time; the notion of perpetual rights, however, is admittedly troublesome. The copyright law again provides a useful analogy, as Chief Justice Bird of the California Supreme Court recently has suggested. ${ }^{20}$ In its present form, the law provides that copyright in an author's work continues until fifty years after his death; a possibility is to apply this same ruleor a rule with a similar express period of duration-to the right of publicity. ${ }^{27}$

Recourse to a copyright analogy would resolve most of the concerns voiced by the Sixth Circuit in Memphis Development Foundation. While it is true, as the court indicated in that case, that our legal system does not allow personal attributes to be devised, ${ }^{28}$ a contract providing for commercial exploitation of attributes, like a copyright, is not purely personal; it is a formalized version of an otherwise unrealized possibility. Moreover, both types of rights avoid conflicts with the First Amendment in the same way: by confining their protection within an area in which the value of freely using existing speech is outweighed by the value of encouraging the creation of new speech.

The common policy of copyright law and the right of publicity of motivating individual effort also provides specific limits on the right of publicity; it means that only those who earn their livelihood from exploiting their attributes in some commercial manner, and who contract for such exploitation during their lives, possess an inheritable right. Finally, if the possibility of inherited publicity rights existing in

25. See id. at 1618-20.

26. See Lugosi v. Universal Pictures, 25 Cal. 3d 813, 846-47, 603 P.2d 425, 446-47, 160 Cal. Rptr. 323, 344-45 (1979) (Bird, C.J., dissenting).

27. To be sure, the rule is of a statutory nature. Once having been enacted in a statute, however, and thus ensconced in public policy, it is available for common law decisionmaking by analogy. Moragne v. States Marine Lines, Inc., 398 U.S. 375 (1970). It may be, however, that adoption of any express period of duration of a decedent's right of publicity is more appropriately effected legislatively.

28. See No. 79-1270, slip op. at 5 . 
perpetuity proves troublesome, ${ }^{2 \theta}$ an analogy to copyright law again suggests a solution..$^{30}$

Any new right can be routed by a parade of horribles about its implications, but a defensible analogy suggests that the legal system can still survive after recognizing the right in question. Similarly, any new right can be characterized as unessential, since the legal system has managed without it; a proper policy analysis explains why recognition of the right would be advantageous, even if not essential. A right of publicity that is descendible in certain limited circumstances poses no greater dangers than the similar aspects of the present copyright laws. On the other hand, to maintain that "leaving a good name to one's children is sufficient reward in itself for the individual" 31 is rather harsh on those who have invested their efforts in their name, rather than in the stock market, and constitutes a rather heavy burden to impose on creativity. The inheritance of publicity rights serves to support a major social policy already recognized in the copyright laws. When it can be shown to do so on a basis consistent with the social policy of the First Amendment, it deserves recognition.

29. See id.

30. The Sixth Circuit's decision not to enjoin the sale of the statuettes may be justifiable on other grounds, however. The statue of Presley, itself, being readily characterized as art, not merchandise, is protected by the First Amendment, and is outside the scope of publicity rights. See p. 1130 sttpra. Replicas of the statue could conceivably fall within this same protected category. Of course, it would always be possible to circumvent a prohibition against commercial exploitation by claiming that one was selling replicas of a single artistic work. But judging the good faith and relevance of such a claim is the sort of determination that courts are generally called upon to make. In the Memphis Development Foundation case, the fact that the replicas were received from a nonprofit organization, in return for contributions to finance construction of the original work of art, does take the situation out of the more usual commercial setting.

31. Memphis Dev. Foundation v. Factors Etc., Inc., No. 79-1270, slip op. at 6 (6th Cir. March 6, 1980). 


\section{The Yale Law Journal}

Volume 89, Number 6, May 1980

\section{Alice Armitage Colburn \\ Editor-in-Chief}

\author{
Boris Feldman \\ Note \& Topics Editor \\ James A. Geraghty \\ Scott M. Matheson \\ Roberta Romano \\ Kenneth T. Roth \\ Note Editors
}

Peter A. Barnes

Managing Editor

Mark S. Campisano

Morgan J. Frankel

R. Laird Hart

Robert A. Katzmann

James C. Snipes

Article \& Book Review Editors
William B. Beekman

Craig B. Brod

John M. Campbell

Vincent J. Chiarello

David M. Crowe

Jeffrey P. Cunard

Perry Dane

Stuart A.C. Drake

John D. Echeverria

Neil R. Ellis

Richard H. Fallon

Charles W. Fournier

Simon Friedman

Gregory P. Goeckner

Isabelle R. Gunning
Theodore F. Haas

John C. Harrison

Steven M. Kamp

Michael D. Klausner

Judith A. Lachman

Frederick M. Lawrence

Carol F. Lee

Robert L. McGlasson

Rachel F. Moran

Richard E. Neff

David Nimmer

Russell G. Pearce

Russell V. Randle

Julie A. Roin

Douglas H. Rosenberg
Anne C. Ryan

Patrick W. Shea

Judith A. Shulman

Dwight C. Smith III

Richard S. Soble

Jeffrey W. Stempel

Donald K. Stockdale, Jr.

Richard G. Taranto

Kenneth S. Taymor

Donald J. Toumey

Debra A. Valentine

David E. Van Zandt

Vern R. Walker

Robert L. Willmore

Michael Woodford

Secretaries to the Editors Edna I. Scott, Pamela Willmott

\section{Student Contributors to This Issue}

John D. Echeverria, Land Use Regulation, the Federal Courts, and the Abstention Doctrine

Charles W. Fournier, The Case for Special Juries in Complex Civil Litigation

John Collier Harrison, Peremptory Challenges and the Meaning of Jury Representation

Carol F. Lee, The Federal Election Commission, The First Amendment, and Due Process

Judith A. Shulman, Property Theft Enforcement and the Criminal Secondary Purchaser of Stolen Goods 